\title{
Assaying in Antiquity
}

\author{
Andrew Oddy
}

Conservation Division, The British Museum, London, U.K.

\begin{abstract}
Modern chemical analysis has derived largely from the methods developed in antiquity as a result of the need to assay gold and other precious metals for coin autbentication and other reasons. Surprisingly the three basic assay methods in use 2500 years ago are still employed today.
\end{abstract}

In Aristophanes play 'The Frogs', first performed in 405 B.C., the leader of the chorus says:

'We do not use these (coins) which have not been adulterated, the most beautiful of all coinage, so it seems, and which alone are struck clearly and proven true by ringing, but these worthless bronzes, struck yesterday and today with the foulest stamp.' (1)

This allusion to bronze coins refers to the fact that between 406 and 404 B.C. the Athenian state, hard pressed financially by the cost of the Peloponnesian war, had officially issued silverplated copper or bronze coins (Figure 1) in place of their pure silver coins which had hitherto been widely disseminated throughout the eastern Mediterranean as a result of trade.

The issuing of debased or plated coins of gold or silver is usually a major retrograde step for any government but, apart from such infrequent instances of the 'official' manufacture of 'forgeries', ever since the invention of coinage in Asia Minor towards the end of the 7 th century B.C., forged coins have been made by individuals in the anticipation of a quick profit.

That coin forgery was commonplace in the ancient world is attested by the numbers of surviving counterfeits made of silveror gold-plated base metal. Forgeries exist for virtually all the precious metal coinages struck in antiquity, although they are more frequent from some periods than others. The survival rate of forged coins is, however, bound to be variable, as one of the main sources of ancient coins is the discovery of hoards, and hoarders, by definition, usually select the best available coins for burial. Nevertheless many hoards are known which have included contemporary forgeries, a good example being the 15th-century hoard of gold coins of the kings Edward III to Edward IV found at Fishpool in Nottinghamshire in 1966 (2). This contained two forgeries which had been made by plating gold onto the surface of a silver core by the method of firegilding (3) (Figure 2).

The craftsman's attitude to fraud in the Roman period seems to have been that cheating was a battle of wits between the customer and the artisan. Pliny, who died in 79 A.D., records a method of gilding base metals by sticking gold leaf onto the surface with mercury (4); however he also adds that some craftsmen used a fraudulent technique of substituting the much cheaper white of an egg for the mercury as the adhesive.
In the books of metallurgical recipes which have survived from the Roman and Medieval periods there are numerous descriptions of alloying processes which are said to increase the bulk of silver or gold without changing its appearance. Needless to say, gilding is dealt with in some detail, and the 4th-century A.D. Leyden Papyrus X (5) cites two such recipes, one for gilding copper with a mixture of lead and gold (6) and the other for gilding silver by the fire-gilding technique (7); in each case the recipe states that the gilded objects will pass the test for gold.

The governments of antiquity were extremely concerned that their coinage should not be counterfeited and took care to protect it by laws which prescribed severe penalties for those convicted of forgery (8). Such laws can be traced back to Roman times (9), but perhaps the earliest legal document which deals with forged coins describes a law enacted in Athens in 375 or 374 B.C. and which was recently discovered inscribed on a stone stela (10). The law provided for the establishment of a post of coin-tester in the market place, the duties of the post being to test coins and to pronounce on whether or not the silver was good. In particular it mentioned that coins which were discovered to have either copper or lead cores would be forfeited.

Unfortunately the Athenian law gave no indication as to how the testing was to be carried out, although it is perhaps implied that cutting was at least one of the techniques used, and numerous coins are known from antiquity which have test cuts on the surface, made to ensure that they were not plated (Figure 1). It is also probable that ringing of coins by dropping them on a hard surface was practised, as mentioned by Aristophanes (see quotation above), and doubtless the semi-quantitative heating method might have been employed. The Leyden Papyrus (11) says that gold can be tested by melting it and letting it cool. Pure gold does not change colour, but if silver is present the alloy so treated becomes white and if lead is present it turns black. The same process is described for testing silver(12), which blackens if it contains lead and becomes yellow if it contains copper. Pliny records the same procedure, but classifies the silver according to the colour generated by heating (13). He also mentions one other qualitative test for silver by claiming that polished pure silver is more easily misted by breathing on it than is silver which has been debased. 
However, apart from these rather rough and ready techniques for testing precious metals the Greeks knew of three quantitative methods for assaying gold and silver and all three are still in use today, two of them in the assay offices of the world (fire assay and the touchstone) and the third in various museum laboratoties for the nondestructive analysis of gold coins (specific gravity measurement by the Archimedes method).

\section{Fire Assay}

Among the earliest references to the assaying of gold is a document dating from the reign of the Egyptian Pharaoh Amenhophis IV (1377-1358 B.C.), written on one of the cuneiform tablets (Figure 3) known as the Amarna letters, in which King Burraburiash of Babylon (1385-1361 B.C.) complains to the Pharaoh that when a recently received

Fig. 1 (Top) The small coin shown at left is an Athenian silver-plated drachm issued in 406-404 B.C. The larger Athenian silver tetradrachm on the right shows cuts on the surface made to test the quality. This coin is from the ath century B.C.

Fig. 2 (Middle) Gold-plated forged coins from the time of Henry VI (1422-1461) and discovered in the Fishpool hoard

Fig. 3 (Bottom) Cuneiform tablet of King Burraburiash of Babylon (1385-1361 B.C.) which records the assaying of a consignment of gold from Egypt

Gold Bull. , 1983, 16, (2)
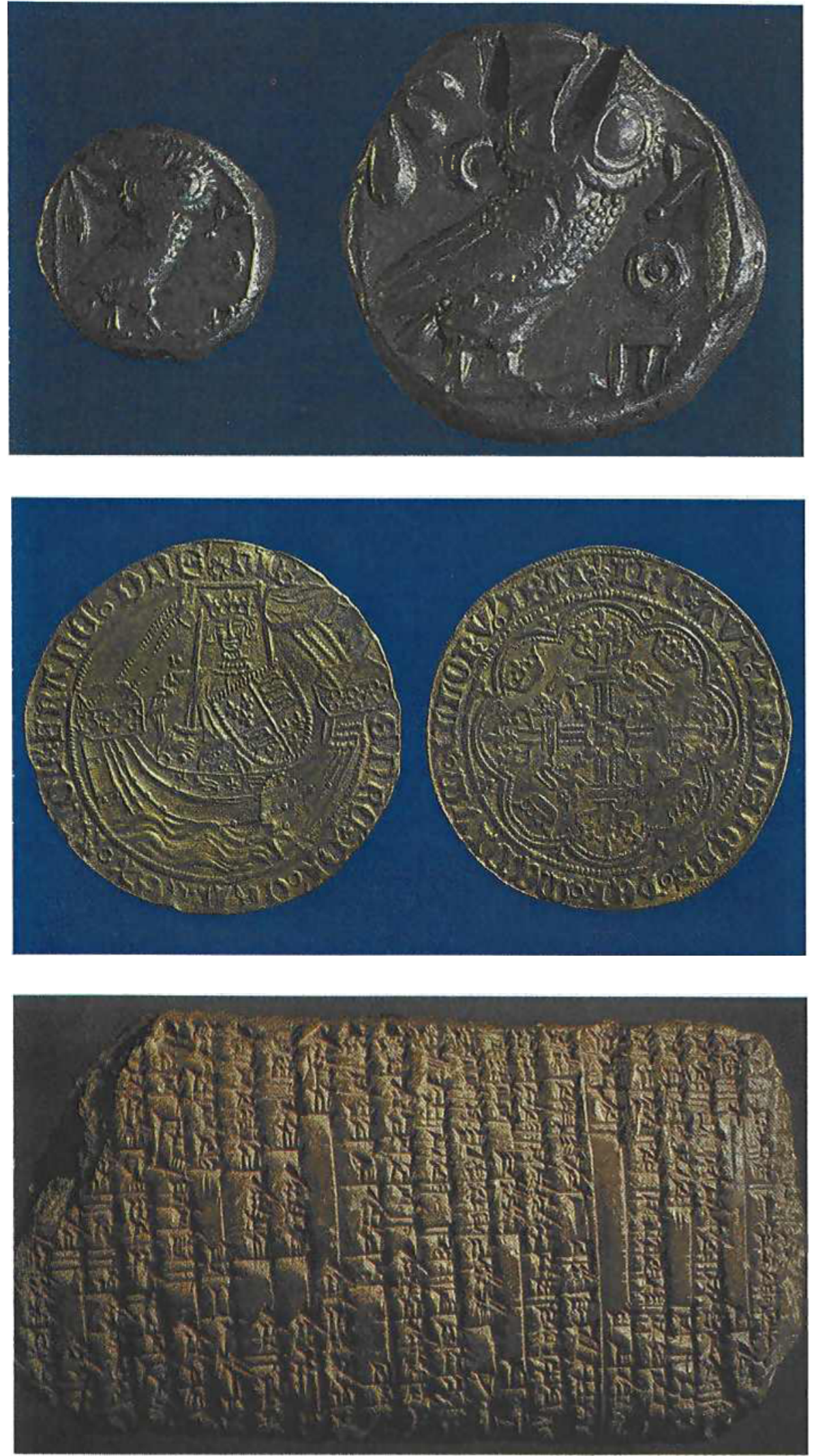


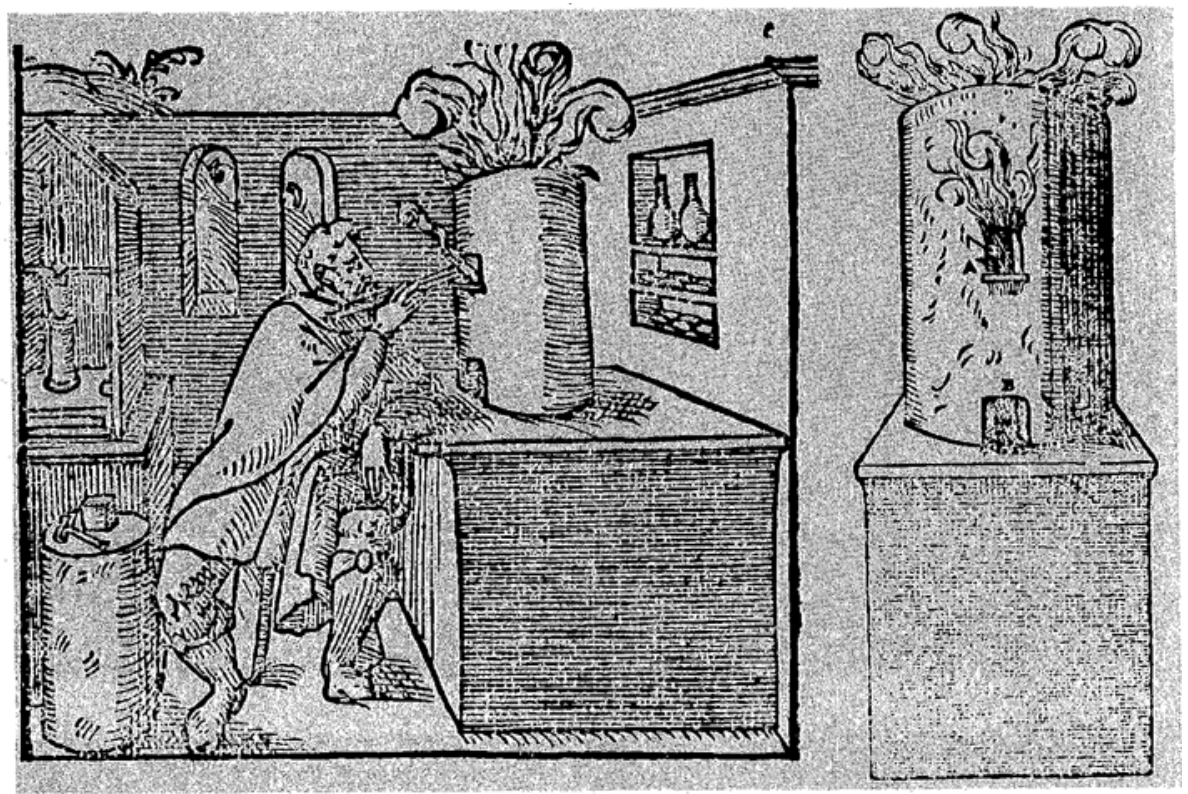

Fig. 4 Furnace for fire assay from Juan de Arphe y Villaphane, 'Quilatador de la Plata, Oto y Piedras', Valladdid, 1572

consignment of gold was tested in the furnace, only one quarter of the original mass was left at the end of the process (14). What is referred to, of course, is not true assaying in the sense that a sample is removed for analysis, but rather the quantitative refining of an alloy. Nevertheless, this text is typical of numerous references to the purification of gold dating from the second and first millennia B.C. (15).

The essentials of fire assaying are the addition of excess lead to the gold, followed by melting in a special crucible under an oxidizing flame (Figure 4). The alloying elements (apart from silver) and the lead are oxidized and the resulting dross is absorbed into the ceramic crucible, leaving behind the gold and any silver which it contains. In antiquity these two metals were then parted by strongly heating in a crucible filled with a mixture of brick dust, vitriols (that is to say, copper and iron sulphates) and salt (the cementation process) which converted the silver to silver chloride. This latter was absorbed by the brick dust and the gold was recovered unaffected (16). Another parting technique, described by Theophilus in the 12th century A.D. (17) consisted of heating the gold-silver alloy with sulphur, which reacts with silver but not with gold. A variation on this technique was to heat the alloy with antimony sulphide, which converts silver to its sulphide, but which alloys some of its antimony with gold. These metals ate then separated by further heating (18). This method was first described in the early 16th century, but its origins are uncertain (19). Finally, with the discovery of nitric acid in the Middle Ages, the modern method of parting by simply dissolving the silver out of the gold was developed.

The origins of the cupellation process are unknown, but excavations at Sardis in Asia Minor have uncovered a workshop area, dating from the 6th century B.C., which is thought to have been used for the large-scale purification of electrum (the naturally occurring gold-silver alloy) by cupellation and for the parting of silver and gold by cementation (20).

Apart from these excavations, the evidence for the history of cupellation and parting is derived from ancient authors who allude to the process. Among the earliest are biblical references in the books of Isaiah (8th century B.C.) Jeremiah (7th century B.C.), Ezekiel (6th century B.C.) and Malachi (5th century B.C.) (21), but the earliest technical description appears to be an Indian Sanskrit document, known as the Arthasâsta of Kautilya, which describes the purification of gold by melting it with four times as much lead as there is impurity in the gold (22). The date of the Arthašâstra is uncertain; most scholars think that the earliest parts of it are from the 3 rd century B.C., but with later additions. The same process is mentioned in the 2 nd century B.C. by Diodorus Siculus (23), and one century later Strabo (24) states that silver can be burnt out of gold by fire, but does not directly mention the addition of salt, although earlier in the text he mentions vitriol, which comprises one of the ingredients of the parting process, and so this latter is what must have been meant.

Pliny describescupellation with lead and the use of vitriol and salt for parting gold and silver (25). He also mentions the use of special crucibles, but says that they were made of white clay (26), whereas by medieval times cupels contained a large amount of bone ash. Other references in Diodorus Siculus and Cassiodorus to the use of special cupels have been collected together by Forbes (27). Some 16th- or 17th-century cupels have recently been excavated on the site of the medieval mint in the Tower of London (28) (Figure 5). 
The 4th-century A.D. Leyden Papyrus has a recipe for colouring gold which is, in reality, a method of parting gold and silver by heating with vitriol and salt, or vitriol, salt and alum (29). The Papyrus also describes the cupellation of silver as a method of purifying the metal, but contains no mention of quantitative measurements (30). In fact the quantitative use of cupellation is not described by any of the classical authors, although there seems little doubt that the process was used quantitatively as swinging balances had been available since the Bronze-Age. By the Roman period these were capable of weighing to about plus or minus $0.1 \mathrm{~g}$.

One of the earliest medieval accounts of cupellation is contained in the work of the great Islamic alchemist Abu Musa Jäbir ibn Haiyaan, known to Western alchemists as Geber. He described the manufacture and use of cupels and clearly stated that they should contain a large proportion of bone ash (31). Geber lived in the 8th century A.D., but the works attributed to him were added to considerably in later centuries. In the 12 th century A.D. Theophilus described cupellation as a means of purifying silver (32), but not of measuring purity. However, in the same century Richard Fitz Nigel (the Bishop of London) clearly alluded to the process as a quantitative method of assay when discussing the quality of the coin of the realm (33). The process is again mentioned for the assay of the English silver coinage in 1280 (34) and for the assay of the newly introduced gold coinage of Edward III around 1350(35). These dates bring us within the known history of the Worshipful Company of Goldsmiths of London which was in existence by at least 1179 , received its first Royal Charter in 1327 and appointed its first full-time assayer in 1478 (36) (Figure 6). Soon after this the first printed descriptions of the techniques of assaying appeared, spreading knowledge of the techniques of cupellation to all who could read $(37,38)$ (Figure 7$)$.

\section{Archimedes Method}

This method of assaying depends on the fact that the specific gravity of gold $\left(19.3 \mathrm{~g} / \mathrm{cm}^{3}\right)$ is nearly twice that of silver $(10.5)$ and more than twice that of copper (8.9). Thus, as gold is debased with these metals its specific gravity is progressively reduced, and may be used as an indication of the extent of the debasement. The discovery of this fact is traditionally ascribed to the philosopher Archimedes (about 287-212 B.C.) who is supposed to have leapt from his bath and run home naked shouting 'Eureka' when he realised that a solid immersed in a liquid suffers an apparent loss in mass equal to the mass of displaced liquid. Archimedes used this principle to check whether a craftsman, who had made a crown for King Hiero, had added any base metals to the gold (39).

It is, however, a long step from establishing the principle to using it as an accurate method of analysis, and the first indication of the use of Archimedes' method as a quantitative technique is in the 6 th century A.D. (40). It is then described in several manuscripts of the period from the 10th to the 13th centuries (41) including the manuscript known as 'Heraclius', which is a list of craftsmen's recipes for making pigments and carrying out various metallurgical operations (42). Another, more accurate, description is to be found in the book of recipes known as the 'Mappae Clavicula' (43), which were probably first collected together in the 8th century A.D., although the description of Archimedes' assaying method appears to be a 12th-century addition. In this early period both pans of the balance were immersed in a tank of water, and the gold-silver alloy had to be weighed with pure silver weights (to avoid errors caused by the difference in the specific gravities of silver and brass, the latter being the usual metal for balance weights) (Figure 8).

One mention of Archimedes' method in connection with gold coins occurs in a 14th-century Islamic book written in Morocco, which specifically states that forged coins can be detected by weighing first in air and then in water (44). In the post-medieval period there was considerable interest in automating specific gravity determinations and, among others, both Galileo and Robert Boyle designed specially graduated balances to simplify the calculation of the results (45).

Nevertheless, in spite of knowledge of Archimedes' principle for over $\mathbf{2} 000$ years, it is only in modern times that it has been used for accurate assay work, one application being for the analysis of ancient gold coins by numismatists and museum scientists (46).

\section{Touching}

Cupellation and Archimedes' methods rely or the accurate weighing of the sample to be analyzed, and their accuracy is thus directly related to that of the balances available to the assayers. The third method of quantitative analysis which was known in the ancient world is, however, essentially nondestructive.

Touching involves rubbing the alloy under investigation onto the surface of a piece of smooth, fine-grained, slightly abrasive, black stone and comparing the colour of the streak produced with those obtained from standard alloys (47). The accuracy of the method depends on knowing whether the alloying element in the gold is silver or copper and on having a suitable range of standard alloys for comparison with the unknown sample. Nevertheless Theophrastus (371-288 B.C.) claimed that touchstones could be used with an accuracy of 1 part in 144 (48) and Pliny (23-79 A.D.) said that a touchstone would 'detect silver or copper to a difference of a scruple' (49). Unfortunately Pliny did not say in how much mass the scruple difference could be detected, but there were 24 scruples in a Roman ounce and 288 scruples in a Roman pound, and it seems most likely that the touchstone was accurate to 1 part in 24 , that is an accuracy of about 2 percent. This is supported by evidence from the analysis 


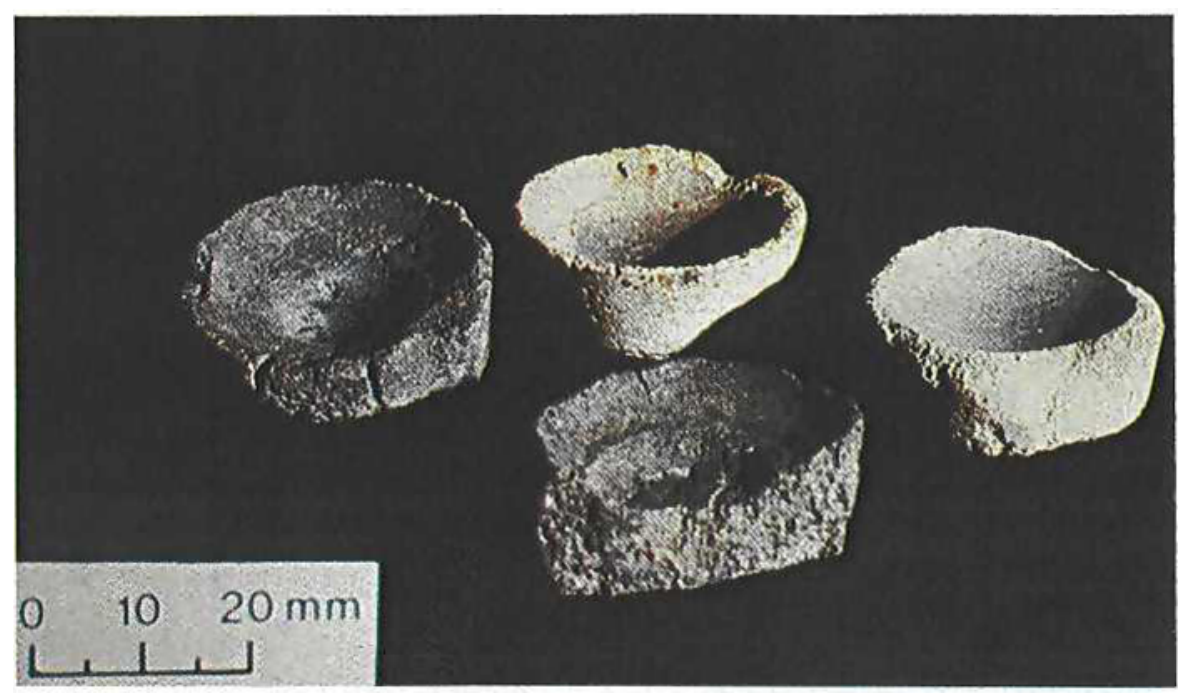

Fig. 5 Cupels from the site of the Tudor mint in the Tower of London

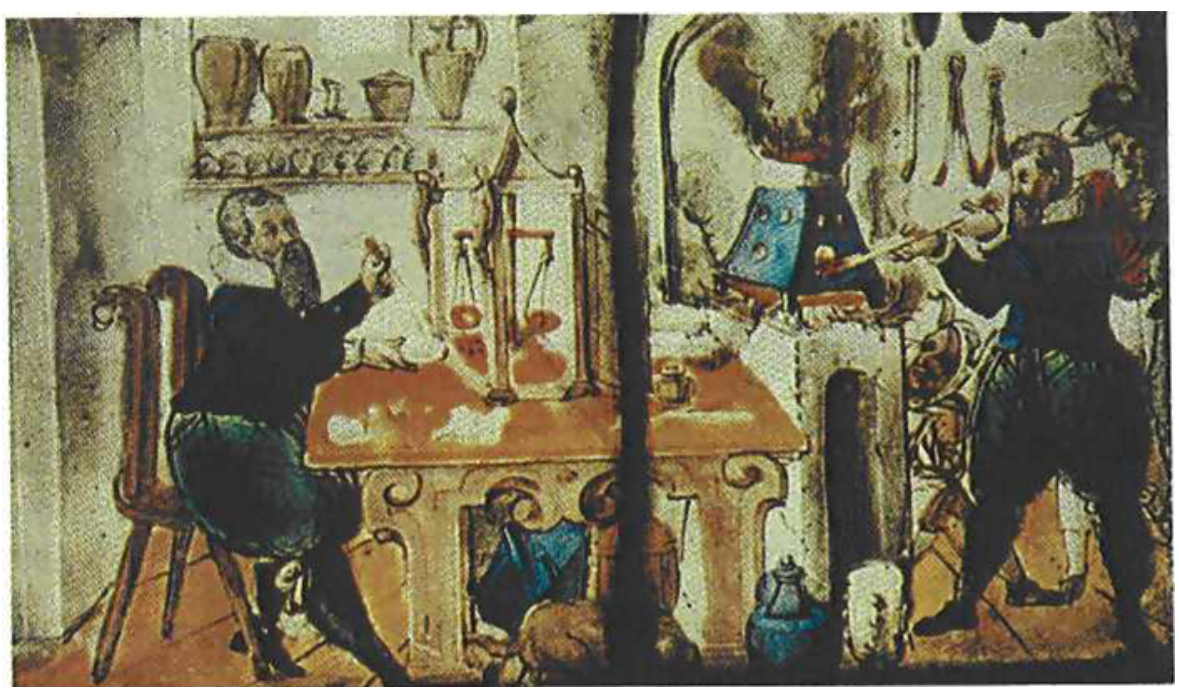

Fig. 6 Weighing (left) and fire assaying (right) are depicted through a window, dated 1624 in Constance, Switzerland

of early medieval coins ( 50 ).

The earliest references to the use of the touchstone have been discussed by numerous authors (51), and appear to start with the Greek poet Theognis in the Gth century B.C., although Bogaert has postulated its origin in Egypt in the 12th century B.C. (52). Mentions are also to be found by the historian Herodotus ( 5 th century B.C.) and in 'Agamemnon' by Aeschylus (about 460 B.C.) and in 'Oedipus 'Tyrannus' by Sophocles (about 420 B.C.). However, it is not until the book on stones by Theophrastus (371-288 B.C.) that a detailed description of touchstones was given, including the information that they could be obtained from only one site in Asia Minor. The touchstone method of assay is discussed in the Sanskrit Arthašâstra ( 3 rd century B.C. with later additions) which also describes the manufacture of a set of touchneedles (standard alloys) in which the ratio of gold to copper is varied in steps of $1 / 16$ (that is $1^{1 / 2}$ carats) (53).

After Pliny, the touchstone is mentioned in passing in the 4th-century Leyden Papyrus X, but Western sources are then surprisingly silent until the appearance of a law of Edward I (promulgated in 1300 A.D.), which refers to a standard for gold alloys known as the 'touch of Paris' (54), and a document of about 1350 , which states that an 'assay of gold may also be made by the touchstone; but that assay can only be determined by experts in the art, and hardly by them without frequent failures.' (55)

This latter statement is, perhaps, rather pessimistic, and an Islamic treatise written about the mint in Cairo, in the early 13th century (under the Ayyubid dynasty) describes the use of the touchstone and the provision of touchneedles in which the ratio of gold to silver is varied in steps of $1 / 24$ (that is one carat) (56). This is the same accuracy as is deduced above from the incomplete description in Pliny. Strangely, the earliest Chinese reference to the touchstone appears to date from 1387 A.D (57), but the technique was (and is) widely used in the East so that by the 19th century Gowland, who had seen the method in use in Japan, could write that accuracies of better than plus or minus 1 per cent were obtainable by skilled craftsmen (58).

As with the other two methods of assaying the touchstone and its use are fully described in numerous printed books which began to make their appearance in the early 16 th century (Figure 9), and it is still widely used today, not only as a rough qualitative check of whether a piece of scrap metal contains any gold, but also as an accurate method of analysis in numerous official assay offices.

However, unlike the other two methods, for which there is thus far no physical evidence for their use in antiquity, 


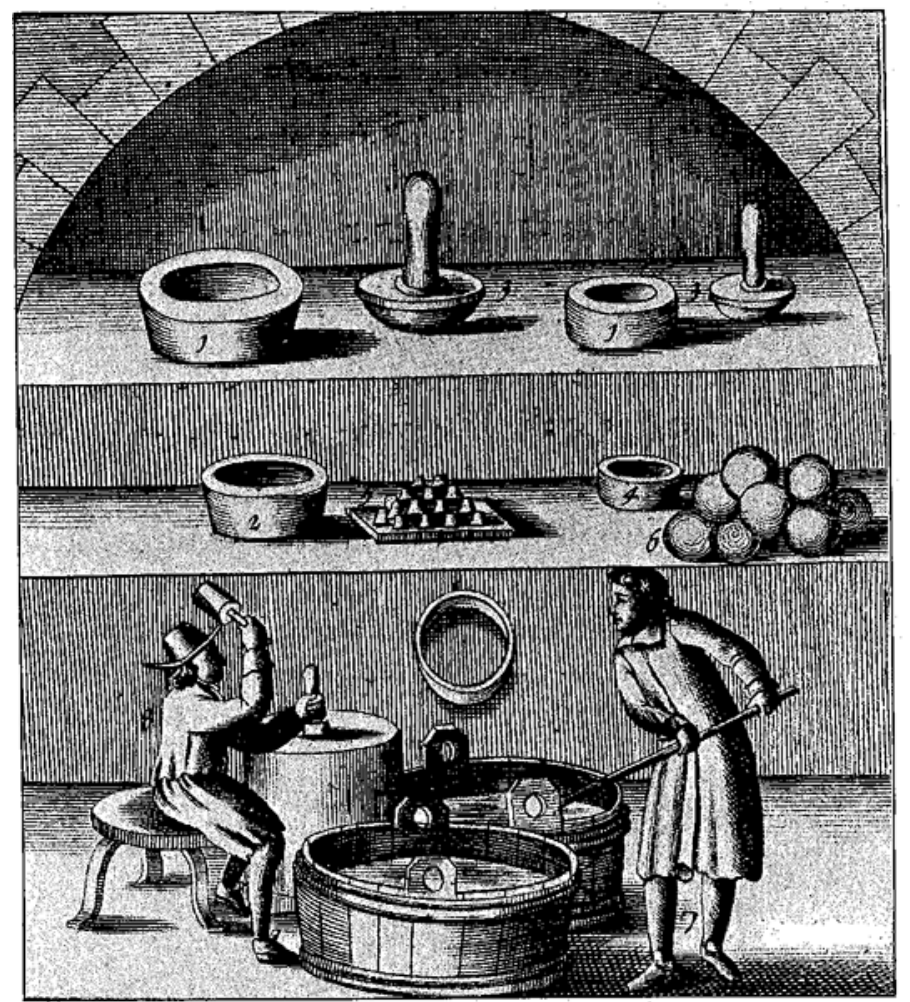

Fig. 7 The manufacture of cupels from Sir John Pettus, 'The Laws of Art and Natureinknowing, judging, assaying, fining, refining.... Metals', London, 1686

touchstones are to be found in the archaeological record, the earliest known ones being from the 6 th $/ 5$ th century B.C. levels of the Bhir mound at the ancient city of Taxila in what is now Pakistan (59). Some of these were described by the excavator as being black natural pebbles while others were pieces of hard siliceous slate cut into long strips and still retaining traces of gold streaks on their surface.

One touchstone is known to have been found at the Iron Age hill-fort of Hengistbury Head, Hampshire (60) but no touchstones appear to have been recorded from Roman sites, although this is likely to be due to a failure to recognise them for what they are, and there is little doubt that many touchstones are misidentified in museums as hone- or whet-stones used for sharpening tools.

For the early medieval period numerous examples of touchstones are known $(61,62,63)$ (Figure 10), many of them still retaining traces of gold on the surface, and a recent petrological analysis of some of them has shown that three main types of rock were used, tuffs, cherts and siltstone, with various other types being used occasionally (64).

By the Renaissance period, and later, the sets of touchneedles had grown to include ternary alloys of gold, silver and copper in which the silver to copper ratio was varied to facilitate the assay of a wide range of alloys and the touchstones had grown with

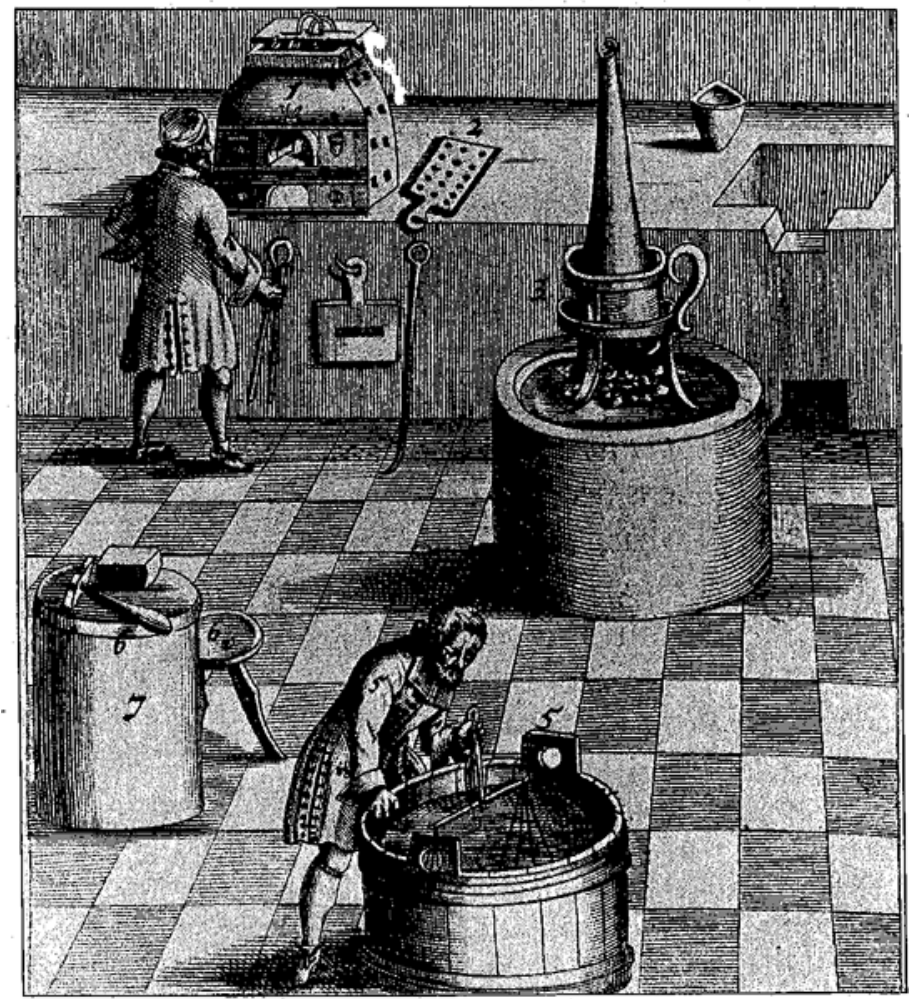

Fig. 8 Specific gravity measurement with both pans of the balance immersed, as was the practice in early times, from Sir John Pettus, "The Laws of Art and Natureinknowing, judging, assaying, fining, refining... Metals', London, 1686

Fig. 9 Touchstones (B) and touchneedles (A) from Juan de Arphe y Villaphane, 'Quilatador de la Plata, Oro y Piedras', Valladdid, 1572, with the streaks (C to F) produced by rubbing alloys and standards onto the stone

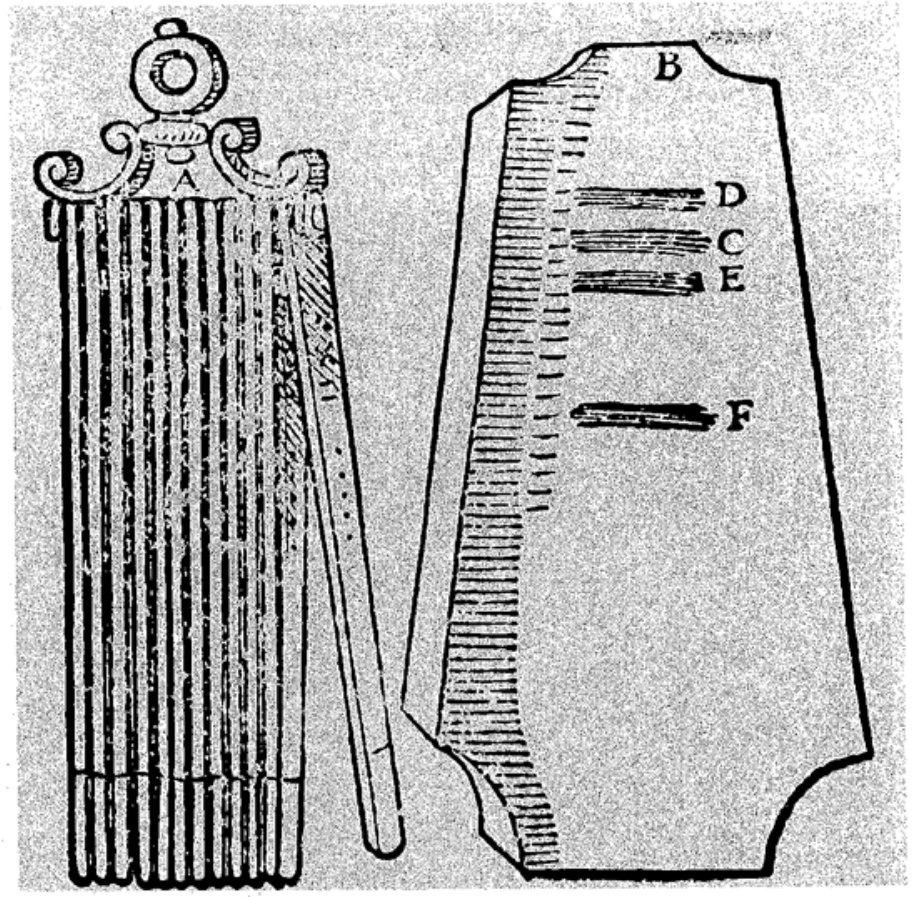




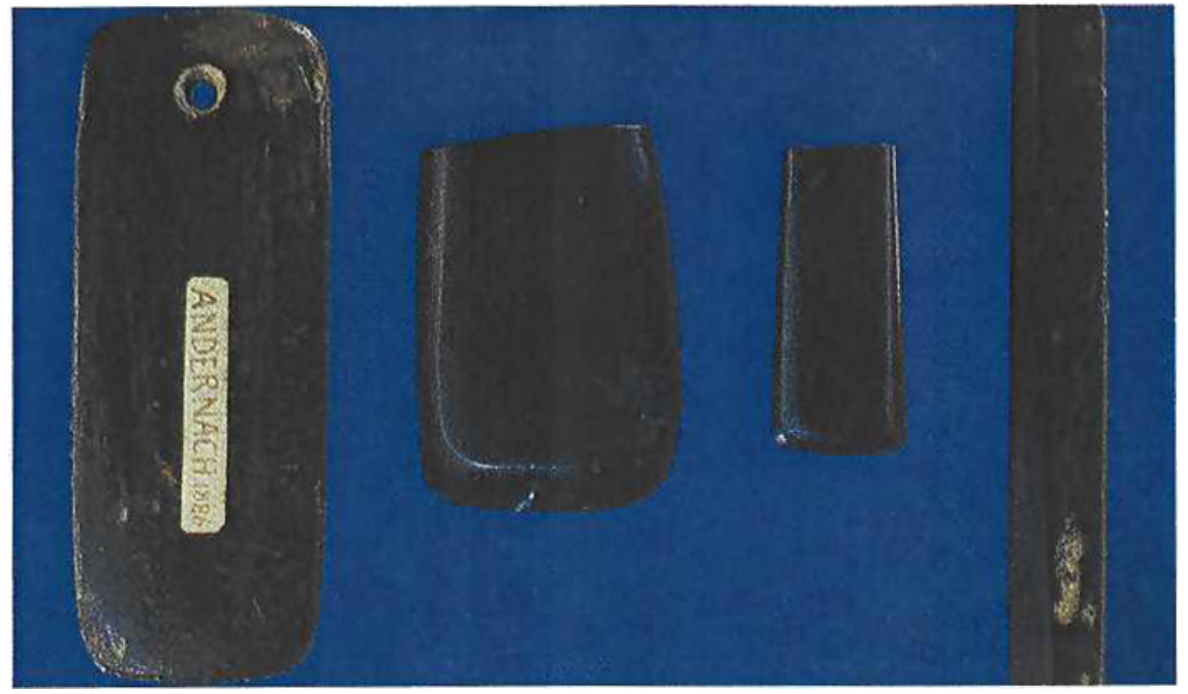

Fig. 10 Early medieval touchstones from (lett to right): Andernach (?6th/7th century A.D.), Ozengell, Kent (late 7th century A.D.), Winchester (10th century A.D.), and Winchester (9th century A.D.)

them so that some examples were very large tablets of black stones, often fitted with handsome metallic mounts (Figure 11).

All the ancient sources are in agreement that the best touchstones should be black, but the Sanskrit Arthasâstta relates that the artisan can cheat the customer by secreting red chalk behind a fingernail and introducing it onto the streak as the metal is rubbed on the stone. The same source also adds that if the artisan is selling gold it would be to his advantage to use a stone with a greyish-green tinge, and if he is buying gold he should use a stone of uneven colour (65). These remarks reflect the medieval recipes, quoted above, by which the craftsmen of a later period sought to cheat their customers with debased or plated metals.

\section{Concluding Remarks}

The methods developed in antiquity for the assaying of precious metals, in particular gold, are the ancestors of modern chemical analysis, and the need to be able to determine the composition of a manufactured material is the basis for all quality control. In view of the rapid advances made in the techniques of chemical analysis in the past thirty years it is very surprising that the three techniques known to the Greeks of 2500 years ago are still in use.

\section{Acknowledgements}

The author's gtateful thanks are due to all those Museum Curators and excavators who have loaned touchstones for study during the past few years. I am also grateful to Judith Swaddling for references to assaying in Greek literature

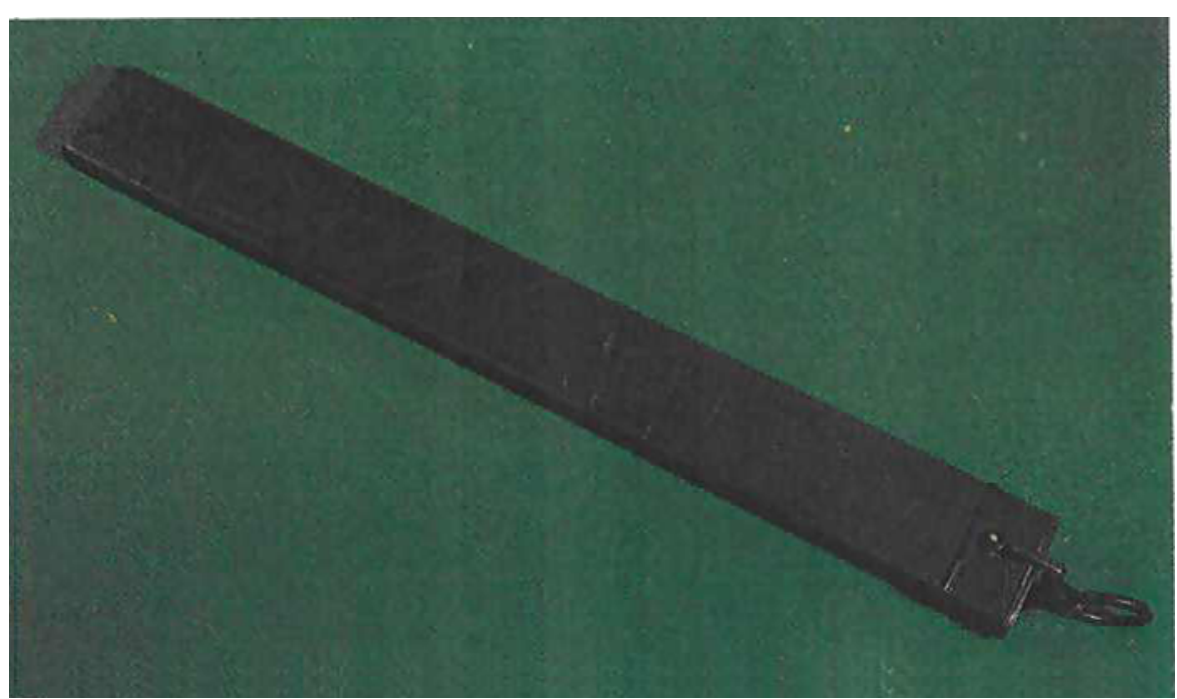

Fig. 11 Large touchstone which was originally from the Royal Mint, London and is now in the Science Museum. Probably 18 th or 19 th century A.D.

Crown Copyrigbt. Science Museum, London 
and translating the quotation from Aristophanes, to George Boon for loaning a slide of the stained glass window in Constance (Figure 6), to the Ancient Monuments Laboratory of the Department of the Environment for the slide of the cupels from the Tower of London (Figure 5) (which is reproduced with the permission of the Controller of Her Majesty's Stationery Office) and to the excavator, Mr. G. Parnell, and to the Science Museum for a slide of its large touchstone (Figure 11). The other illustrations (Figures 1-4, 7, 8, 9 and 10) are reproduced by permission of the Trustees of the British Museum.

\section{References}

1 Aristophanes, Frogs, 721-726

2 M.M. Archibald, 'Fishpool, Blidworth (Nottinghamshire), 1966 Hoard: Inerim Report', Numismatic Chron., 7th Series, 1967, 7, 133-146

3 W.A. Oddy, unpublished data

$4 \mathrm{H}$. Rackham, 'Pliny. Natural History', Vol. IX, Loeb Classical Library, London, 1952 (reprinted 1968), p. 77

5 R. Halleux, 'Les Alchimistes Grecs', Tome 1, Papyrus de Leyde, Papyrus de Stockhom, Fragments de Recettes, Société d'Édition Les Belles Lettres, Paris 1981. See pp. 22-24 for a discussion of the date

6 See (5), No. 37, p. 93

7 See (5), No. 55, p. 97

8 D.M. Metcalf and F. Schweizer, 'The Metal Contents of the Silver Pennies of William I and Henry I (1087-1135)', Archaeometry, 1971, 13, 177-190

9 P. Grierson, 'The Roman Law on Counterfeiting', in 'Essays on Roman Coinage Presented to Harold Mattingly', edited by R.A.G. Carson and C.H.V. Sutherland, Oxford, 1956. pp. 240-261

10 R.S.Stroud, 'An Athenian Law on Silver Coinage', Hesperia, 1974, 43, (2) 157.188

11 See (5), No. 42.p. 95

12 See (5), No. 43, p. 95

13 See (4), pp. $95-97$

14 J.A. Knudtson, 'Die El-Amarna-Tafeln', Leipzig, 1915, pp. 90-95

15 M. Levey, 'The Refining of Gold in Ancient Mesopotamia', Chymia, 1959, $5,31-36$

16 J. Needham, 'Science and Civilisation in China' Vol. 5, Part II, Cambridge University Press, Cambridge, 1974 , p. 39

17 J.H. Hawthorne and C.S. Smith, 'Theophilus - On Divers Arts', 'The Chicago University Press, Chicago, 1963 (reprinted Dover, New York, 1979), p. 147

18 D. Stockdale, 'Historical Notes on the Assay of Gold', Sci. Prog., 1924, 18, 476-479

19 See (16)

20 G.M.A. Hanfmann and J.C. Waldbaum, "The Eleventh and Twelfth Campaigns at Sardis $(1968,1969)$ ', in 'Bulletin of the American Schools of Oriental Research', No. 199, 1970, 7 ff.

21 See (16), p. 40

22 M.K. Pal 'Crafts and Craftsmen in Traditional India', Kanak Publications, New Delhi, 1976, p. 255

23 J.F. Healy, 'Greek Refining Techniques and the Composition of GoldSilver Alloys', Revue Belge de Numismatique, 1974, 120, 19-33, especially $25 \mathrm{ff}$.

$24 \mathrm{See}(23), 27 \mathrm{ff}$

25 See (4), pp. 49 and 65-67

26 See (4), p. 55

27 R.J. Forbes, 'Studies in Ancient Technology, VIII', Leiden, 1971, p. 177

28 These were shown to me by the excavator, Mr. G. Parnell, and by Mr. L. Biek and Miss J. Bayley of the Ancient Monuments Laboratory, London

29 See (5), No. 24, p. 91

30 See (5), No. 25 , p. 91

31 E.J. Holmyard, 'The Works of Geber Englished by Richard Russell, 1678', .M. Dent \& Sons Ltd., London, 1928, pp. 183-184

32 See (17), p. 96

33 C.Johnson, 'The Course of the Exchequer by Richard, Son of Nigel', T Nelson \& Sons Ltd., London, 1950, p. 37

34 C.Johnson, 'The De Moneta of Nicholas Oresme and English Mint Documents', London, 1956, p. 67

35 See $(34)$, p. 84
36 T.F. Reddaway and L.E.M. Walker, 'The Early History of the Goldsmiths' Company' E. Arnold, London, 1975

37 J.P.Phillips, '16th Century Texts on Assaying', Chem. Ediuc., 1965, 12, (7), 393-394

38 C.S. Smith, 'Metallurgy and Assaying', in 'A History of Technology: Vol. III: from the Renaissance to the Industrial Revolution', edited by C. Singer et al., Clarendon Press, Oxford, 1957, pp. 27-71

39 F. Granger, 'Vitruvius on Architecture', Vol. 2, London, 1970, pp. 203-207

40 M. Clagett, 'The Science of Mechanics in the Middle Ages', Madison, 1959

41 C.S. Smith and J.G. Hawthorne "Mappae Clavicula: A Little Key to the World of Mediaeval Techniques', Trans. Am. Philos. Soc., New Series, $1974,64,(4), 56$ see footnote 131

42 M.P. Merrifield, 'Original Treatises.... on the Arts of Painting in Oil', London, 1849 , pp. 226-227

43 See (41), p. 56

44 C. Toll 'Minting Technique According to Arabic Literary Sources', Oriental Suecana, 1970-1971, 19-20, 125-139, especially 135

45 See (41)

46 W.A. Oddy, 'Gold in Antiquity: Aspects of Gilding and of Assaying', J.R. Soc. Arts, 1982, 130, (5315), 730-743, especially 741

47 W. Wälchli, 'Touching Precious Metals', GoldBull., 1981, 14, (4), 154-158

48 E.R. Caley and J.C. Richards, 'Theophrastus on Stones', The Ohio State University, Columbus, OH., 1956, p. 155

$49 \operatorname{Sec}(4)$, p. 95

50 J.P.C. Kent, 'The Date of the Sutton Hoo Hoard', in R. Bruce-Mitford, 'The Sutton Hoo Ship Burial', Vol.I, The British Museum, London, 1975, pp. 588-607, especially pp. 590-591

$51 \mathrm{See}(23)$, pp. $30 \mathrm{ff}$.

52 R. Bogaert, 'L'essai des monnaies dans l'antiquité', Revue Belge de Numismatique, $1976,122,5-34$, especially pp. $8 \mathrm{ff}$.

53 R.P. Kangle, 'The Kautiliya Arthaŝâstra (Part II)', Bombay, 1963, pp. 128-129

54 S. Hare, 'Touching Gold and Silver: 500 Years of Hallmarks', (Catalogue of an exhibition held at Goldsmiths' Hall, Foster Lane, London, in November, 1978), London, 1978 , p. 14

$55 \operatorname{Sec}(34)$, p. 85

56 M. Levy, "Mediaeval Arabic Minting of Gold and Silver Coins', Chymia, 1976,$12 ; 3-14$, especially 7

57 J. Needham, 'Science and Civilisation in China' Vol. 3, Cambridge University Press, London, 1959, p. 672

58 W. Gowland, 'Japanese Metallurgy I: Gold and Silver and their Alloys', I Soc. Chem. Ind., 1896, 15, $404 \mathrm{ff}$.

59 J. Marshall, 'Taxila', Vol. II, Cambridge University Press, Cambridge, 1951, p. 502

60 W. Gowland, 'Appendix II: Report on the Metals and Metallurgical Remains', in J.P. Bushe-Fox 'Excavations at Hengistbury Head, Hampshire, in 1911-12' Reports of the Research Committee of the Society of Antiquaries of London, No. 3, London, 1915, pp. 72-83

61 See (46), 740-741

62 V. Zedelius, 'Coticulae, Merowingerzeitliche Probiersteine im nördlichen Rheinland', in 'Das Rheiniche Landesmuseum, Bonn: Berichte aus der Arbeit des Museums', No. 4, 1979, pp. 58.59

63 V. Zedelius, Merowingerzeitliche Probiersteine im nördlichen Rheinland', Der Anschnitt, 1981, 31, (1), 2-6

64 D.T. Moore and W.A. Oddy, "Touchstones: Some Aspects of their Nomenclature, Petrography and Provenance', in preparation for J. Arch aeol. Sci.

65 See (53), p. 128 